\title{
IDAHO CHEMICAL PROCESSING PLANT SITE DEVELOPMENT PLAN
}

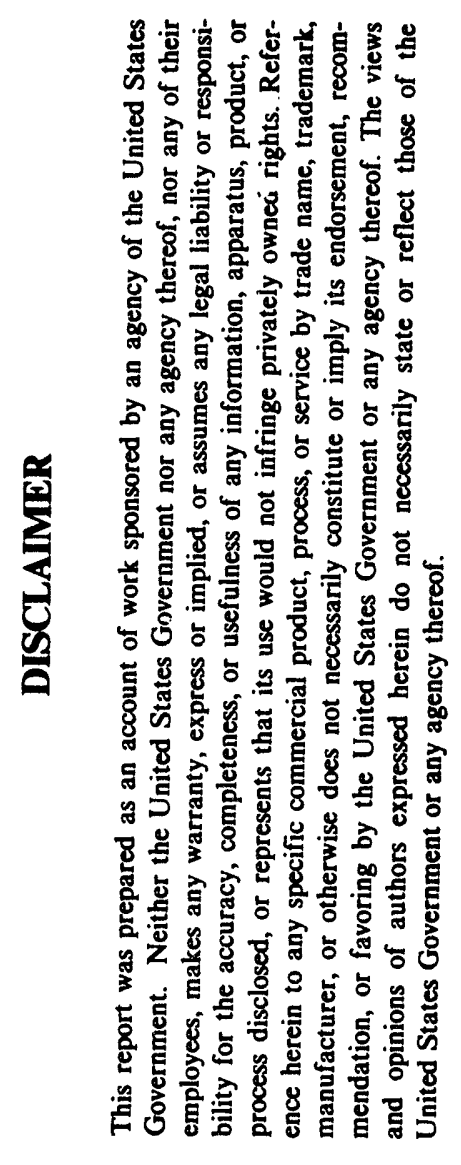

\author{
F. G. Ferguson
}

February 1994

\section{Westinghouse Idaho}

PREPARED FOR THE

\begin{abstract}
DEPARTMENT OF ENERGY IDAHO OPERATIONS OFFICE

UNDER CONTRACT DE-AC07-84ID12435
\end{abstract}


CONTENTS

1.0 EXISTING MISSIONS, WORKLOAD, AND SITE POPULATION $\ldots \ldots \ldots \ldots$

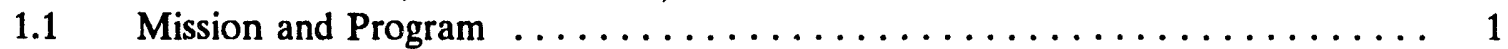

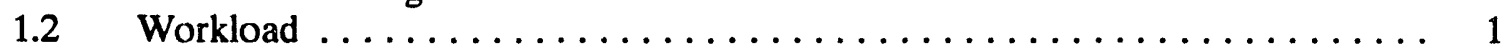

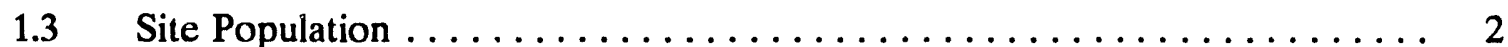

$2.0 \quad$ SITE AND REGIONAL INFORMATION $\ldots \ldots \ldots \ldots \ldots \ldots \ldots \ldots \ldots \ldots \ldots$

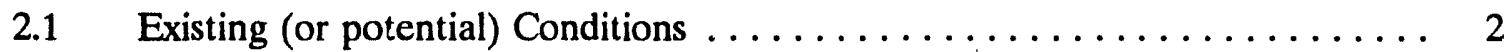

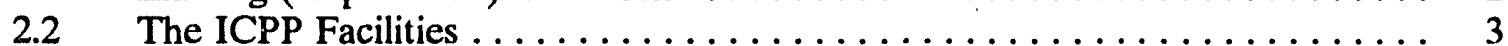

2.2.1 Condition of Facilities $\ldots \ldots \ldots \ldots \ldots \ldots \ldots \ldots \ldots \ldots \ldots \ldots$

2.2.2 Conditions that would enhance/deter

establishing new missions ................... 4

2.2.3 Factors that may influence the future use of the site $\ldots \ldots \ldots \ldots \ldots$

3.0 PROGRAM MISSION PROJECTIONS AND MISSION RESOURCE $\ldots \ldots \ldots \ldots$

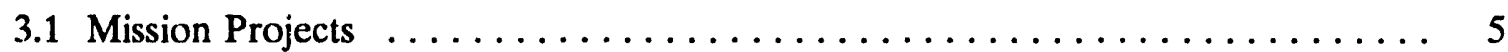

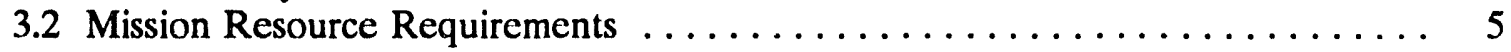

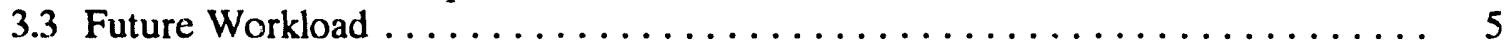

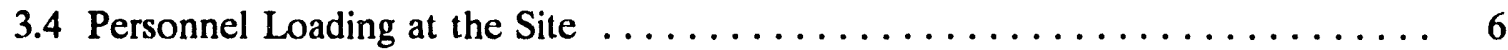

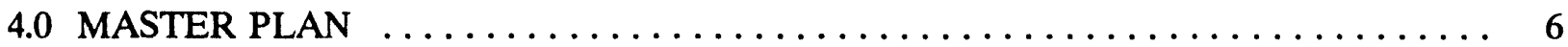

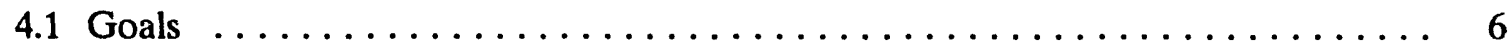

4.2 Facility and Land Requirements and Future Uses $\ldots \ldots \ldots \ldots \ldots \ldots \ldots \ldots$

4.3 Future Major Facility Locations and Construction Programs . . . . . . . . . . 9

4.4 Utility Sources . . . . . . . . . . . . . . . . . . . .

4.5 5-Year Construction Program $\ldots \ldots \ldots \ldots \ldots \ldots \ldots \ldots \ldots \ldots \ldots \ldots \ldots \ldots \ldots \ldots \ldots$

5.0 SPECIAL CONSIDERATIONS $\ldots \ldots \ldots \ldots \ldots \ldots \ldots \ldots \ldots \ldots \ldots \ldots$

FIGURES

Figure 1. 1993 ICPP Facilities $\ldots \ldots \ldots \ldots \ldots \ldots \ldots \ldots \ldots \ldots \ldots \ldots \ldots \ldots \ldots$

Figure 2. ICPP in 2013 (Master Plan map) $\ldots \ldots \ldots \ldots \ldots \ldots \ldots \ldots \ldots \ldots \ldots$

TABLES

Table 1. ICPP Five-Year Construction Project Summary $\ldots \ldots \ldots \ldots \ldots \ldots \ldots \ldots$ 


\section{ACRONYMS}

CSSF Calcine Solids Storage Facility

D\&D decontamination and decommissioning

DOE U.S. Department of Energy

EIS Environmental Impact Statement

FPR Fuel Processing Restoration project

FSV Fort St. Vrain (fuel)

FY fiscal year

HLLW high-level liquid waste

HLW high-level waste

ICPP Idaho Chemical Processing Plant

INEL Idaho National Engineering Laboratory

LI line item

NWCF New Waste Calcining Facility

OSHA Occupational Safety and Health Act

RAL Remote Analytical Laboratory

RCRA Resource Conservation and Recovery Act

TRU transuranic

TSD treatment, storage, and disposal

WIF Waste Immobilization Facility

WINCO Westinghouse Idaho Nuclear Company, Inc. 


\subsection{Mission and Program}

The Idaho Chemical Processing Plant (ICPP) mission is to receive and store spent nuclear fuels and radioactive wastes for disposition for Department of Energy (DOE) in a cost-effective manner that protects the safety of Idaho National Engineering Laboratory (INEL) employees, the public, and the environment by:

- Developing advanced technologies to process spent nuclear fuel for permanent offsite disposition and to achieve waste minimization.

- $\quad$ Receiving and storing Navy and other DOE assigned spent nuclear fuels.

- Managing all wastes in compliance with applicable laws and regulations.

- Identifying and conducting site remediation consistent with facility transition activities.

- Seeking out and implementing private sector technology transfer and cooperative development agreements.

Prior to April 1992, the ICPP mission included fuel reprocessing. With the recent phaseout of fuel reprocessing, some parts of the ICPP mission have changed. Others have remained the same or increased in scope.

\subsection{Workload}

Fucl Reprocessing Phaseout - The decision was made on April 28, 1992, to cease all DOE reprocessing of nuclear fuels. This decision will lead to phaseout of all fuel dissolution, solvent extraction, Rare Gas Plant operations, and product denitration at the ICPP. The reprocessing facilities will be converted to a safe and stable shutdown condition awaiting future decontamination and decommissioning (D\&D).

Fuel reprocessing phaseout is assumed to cover:

- $\quad$ Final process operations including a final uranium sweepdown needed to convert in-process materials to a stable storage form; and

- $\quad$ Process system clean-out necessary to provide an adequate level of safety to the public, in-plant workforce, and environment.

The Fuel Processing Restoration (FPR) project, a new separations facility under construction, was designated to be placed in a lay-up posture for preservation and possible future use. The structural subcontracts were $100 \%$ complete upon closeout, and the total project including the systems and components were over $50 \%$ complete upon closeout. 
Fucl Receipt and Storage - The scope of the fuel receipt and storage function has increased to provide storage for a greater quantity of fuel than was previously planned. The storage capability will be exceeded before newly developed fuel dispositioning technologies can be implemented. The fuel storage facilities are approximately $50 \%$ full. The fuel storage inventory at the ICPP [4Q fiscal year (FY) 1993] is 965 metric tons. This spent fuel mass contains 14.8 metric tons of enriched uranium and 34.2 metric tons of depleted uranium.

Fuel receipts have averaged 40 metric tons mass per year for the past 10 years. The future fuel receipt forecasts show an average of 80 metric tons total mass for the next 36 years. The total inventory in 2013 is anticipated to be 47 metric tons of enriched uranium.

A substantial inventory is expected to accumulate before any alternative disposal method can be established. To support the increase in storage requirements, a storage configuration change must be accomplished.

Waste Management - Waste management includes management of the high-level liquid waste (HLL.W) in the tank farm, conversion of the HLLW to calcine, storage of the calcine in the Calcine Solids Storage Facilities (CSSFs), and management of D\&D and restoration generated wastes.

Research and Technology Development - Research and technology development has expanded greatly and has become a separate functional area. In April 1992, the DOE-ID Field Office released the Draft Spent Fuel and Waste Management Technology Development Plan, which outlines the strategy for management of fuels and wastes at ICPP. This new function encompasses eight areas: (1) systems analysis; (2) radioactive, sodium-bearing liquid waste processing; (3) calcine immobilization; (4) graphite fuel conditioning; (5) special fuel conditioning; (6) development facilities; (7) conversion of existing facilities; and (8) recycle metal/waste minimization.

\subsection{Population}

Westinghouse Idaho Nuclear Company, Inc. (WINCO) employs approximately 1,800 employees to work at the ICPP. During the day the ICPP site population is approximately 1,200 . Four rotating twelve hour shift crews are assigned to operations.

About $40 \%$ of the daytime population is involved in operations activities. The remaining $60 \%$ of the population is engaged in support activities including environmental compliance, safety, engineering, projects, technical support and development, quality assurance, finance, and human resources.

\subsection{SITE AND REGIONAL INFORMATION}

\section{$2.1 \quad$ Fxisting (or potential) Conditions}

The Idaho National Engineering Laboratory's (INEL) history of safe operation, and the large number of people in southeast Idaho who are associated with it, produce a strong reservoir of support near the INEL's home base. However, support in other regions of Idaho has eroded in 
recent years, creating an opportunity for improved relationships in areas like Twin Falls, Boise, and Moscow. This loss of confidence is largely attributable to actions taken by the State of Idaho and Idaho citizen concerns about water quality in the Snake River Aquifer.

Late in 1988, the governor of Idaho banned further shipments to the INEL of defense-related transuranic (TRU) waste from the Rocky Flats Plant and spent fuel from the Fort St. Vrain (FSV) commercial reactor, both located in Colorado. The Shoshone-Bannock Tribes at Fort Hall also opposed FSV shipments across their reservation. DOE agreed to stop importing TRU waste and will not attempt more FSV shipments until a Site-wide Environmental Impact Statement (EIS) is completed in 1995.

The ICPP is the nation's only interim storage facility for spent Navy reactor fuel. The governor obtained a Federal court injunction banning more Navy fuel shipments until completion of the INEL's EIS, which also considers alternate sites for Navy fuel storage. However, the Navy and DOE have appealed a portion of this injunction. Therefore, whether the ICPP will continue to receive Government-owned fuels for interim storage after 1995 is unclear.

The DOE nationwide complex is undergoing significant changes because of reductions in defense needs and increased focus on environmental restoration (cleanup). The DOE Office of Facility Transition, within DOE Environmental Restoration and Waste Management, has been formed to manage facilities that no longer have an identified mission and must undergo a transition to a new use or be decommissioned. The transition process, administered by this new office, covers the change from current mission to deactivation, decontamination, and disposition. Disposition may result in reuse by DOE, release to non-DOE users, or decommissioning.

The future of the INEL will greatly influence the economic growth of southeast Idaho. Both commerce and industry leaders clearly recognize the INEL's economic force and the impact of a substantial reduction in employment due to a change in mission. They will support new, environmentally conscious missions that help INEL transition from defense to civilian goals.

\subsection{The ICPP Facilities}

\subsubsection{Condition of Facilitics}

The condition of the ICPP facilities generally corresponds to the age of the building or structure. Many structures and processes have been upgraded or replaced during the past 10 years, but several facilities designed and constructed in the 1950's do not meet the requirements imposed by current regulations for environmental compliance, seismic qualifications, or employee safety. Structural upgrades to many of these facilities are cost prohibitive; therefore, several new facilities are planned to correct known deficiencies. See section 5.0, Special Considerations, for more information.

When the phaseout is complete, the following facilitics will have been placed in a safe, stable shutdown condition:

- $\quad$ CPP-601 (except the deep tanks and parts of the process makeup area).

- CPP-602 (denitrator area only).

- $\quad$ CPP-627 (hot chemistry lab only). 
- CPP-640 (Rover process phaseout will continue beyond FY-94).

- $\quad$ CPP-631.

- $\quad$ CPP-685.

- $\quad$ CPP-604 (Rare Gas Plant only).

- $\quad$ CPP-633 (Waste Calcining Facility).

- CPP-1614.

- CPP-1633.

\subsubsection{Conditions That Would Enhance or Deter Establishing New Missions}

Existing, new, and proposed program assumptions and forecasts are based on several INEL longrange planning documents, such as the INEL Institutional Plan, Environmental Restoration FiveYear Plan, Environmental Restoration and Waste Management Site Specific Plan, etc. A review of these documents indicates that the existing capabilities at the ICPP will need enhancement to meet the expected program requirements. Some of the existing facilities and equipment are old and in need of replacement. Program requirements will be accomplished by constructing new buildings, expanding existing facilities, and upgrading ICPP utility systems.

An increased emphasis on safety and environmental issues will affect future project costs and schedules. WINCO is committed to comply with these laws, regulations, and requirements.

\subsubsection{Factors That May Influence the Future Use of the Site}

WINCO executes DOE-assigned programs and complies with applicable state and federal laws, regulations, and requirements as directed by DOE. Changes in ICPP mission and future site development are in accordance with the overall needs and guidance received from DOE.

Facilities necessary to accomplish the ICPP mission are planned and constructed based on DOE funding and approval. The most current presentation of WINCO's overall site plan is contained in the Nuclear Fuel Reprocessing Phaseout Plan. Additional planning details are contained in the most recent issue of the following plans:

INEL High-Level Waste Issues and Resolutions Document;

Capital Asset Management Plan;

WINCO Strategic Plan;

Environmental Restoration \& Waste Management Five-Year Plan; and Materials Management Plan.

Future waste and spent fuel management activities will be addressed in an overall INEL environmental impact statement. Future actions involving waste management are defined and will vary only as a function of available funding levels and environmental exposure. 


\subsection{PROGRAM MISSION PROJECTIONS AND MISSION RESOURCE REQUIREMENTS}

\subsection{Mission Projections}

The ICPP mission will continue to include fuel receipt, storage, and processing for disposition; waste processing for disposal in a repository; development and application of technologies to minimize waste generation and management of radioactive and hazardous wastes; and conducting site remediation work and facility D\&D activities.

\subsection{Mission Resource Requirements}

Mission resource requirements are being extensively evaluated due to a recent DOE decision to discontinue reprocessing nuclear fuel at the ICPP. New staff levels are being developed based on the phaseout of fuel reprocessing and on the availability and timing of new programs and missions. Funding is expected to be reduced $10 \%$ in FY 1995 . This may reduce ICPP employment from 1,800 to 1,600 .

The Idaho Chemical Processing Plant Spent Fuel and Waste Management Technology Development Plan, July 1992, outlines the strategy for conducting a Spent Fuel/Waste Management Technical Development Program at ICPP. This program will produce the technology development and demonstration required to ensure that spent fuel and HLLW will be processed for disposal in a repository.

Projected production units for fuel receipt, HLLW generation, calcine production, and the estimated number of immobilized waste canisters prepared for shipping are described annually in materials management plans and Integrated Data Base documents.

\subsection{Future Workload}

The most important activities and projected events during the next 20 years include:

- Improve and increase fuel storage capacity;

- Develop the next generation of fuel and waste management technologies;

- Develop, construct, and operate a waste immobilization process;

- Develop dispositioning and conditioning technologies for spent fuel;

- Develop capabilities to dispose of special nuclear fuels and high-level waste (HLW);

- $\quad$ Provide Resource Conservation Recovery Act (RCRA)-approved treatment, storage and disposal facilities;

- Enhance chemical analysis capabilities to support waste management and environmental sampling; 
- $\quad$ Reduce personnel radiation exposure;

- Conduct environmental compliance and Occupational Safety and Health (OSHA) training;

- Decommission targeted facilities;

- Minimize solid and liquid waste generation;

- Improve hazardous waste management;

- $\quad$ Remediate inactive waste sites;

- $\quad$ Provide adequate utility systems; and

- Build adequate operations support office space and improve warehouse capacity.

\subsection{Personnel Loading at the Site}

Increased emphasis on waste and spent fuel technology development, environmental and safety issues, training, and waste management will change the composition of the workforce. This, coupled with consolidation of the INEL contracts, will result in a redistribution of personnel. ICPP projected population in the year 2013 is 1,200 people.

\subsection{MASTER PLAN}

\subsection{Goals}

The goals listed below will help make the ICPP more effective in accomplishing its scheduled mission(s) during the next 20 years.

- Conduct operations in a manner to minimize environmental and safety risks to employees, the public, and the environment; and fully comply with applicable regulations;

- Construct or upgrade facilities to support mission requirements; and

- Upgrade utilities to adequately support existing and planned programs.

\subsection{Facility and Land Requirements and Future Uses}

Existing land use at the ICPP is illustrated on figure 1. The proposed configuration of the site in 20 years is illustrated on figure 2. Twenty-seven projects are planned at ICPP during this 20 year time frame. Although no additional leasing or land acquisition is required for siting of these facilities, alteration of the secured area may occur. 
Figure 1. 1992 ICPP Facilities 
Figure 2. 2012 ICPP Facilities 


\subsection{Future Major Facility Locations and Construction Programs}

Several new facilities that require line item funding are identified for the planning period. A brief description of the issue(s), resolution(s), and impact(s) of planned line items for the upcoming 20 years is located in section 5.0, Special Considerations.

\subsection{Utility Sources}

The present utility systems will not supply projected utility demands. The utility tunnels and underground utilities have not been extended to areas designated for site development. As a result, new facilities are being located where utilities are available rather than in areas with other similar facilities that support efficient plant operations.

Numerous ICPP facilities are without sanitary sewer service connection to the sewage treatment plant. This situation conflicts with DOE and State of Idaho environmental compliance guidelines.

The electrical distribution system is outdated, overloaded and is not in compliance with DOE orders or national codes and standards.

A line item project is planned for FY96 to enhance and upgrade present utility systems capabilities. Numerous general plant projects are planned to improve various other utility systems including breathing air, potable water well, and sanitary waste lines.

\subsection{Five-Year Construction Program}

New construction, improvements, and upgrades during the upcoming five years are listed on Table 1. Also listed on the table is the funding type, proposed budget year, rough magnitude of cost, and tentative National Environmental Policy Act documentation for proposed modifications to the ICPP in the next five years. Table 1 is found at the end of this document.

\subsection{SPECIAL CONSIDERATIONS}

Listed below are specific site planning issues that need resolution. For each issue listed, a solution, resources commitments, and impact, if the issue is not resolved, is listed. 
Table 1. ICPP FIVE-YEAR PROJECT SUMMARY.

\begin{tabular}{|c|c|c|c|}
\hline Sanitary Waste Lines Upgrade (construction) & GE-GPP & $900 \mathrm{~K}$ & CX Completed \\
\hline CPP-603 Waste Tank Upgrade (design) & GE-GPP & $150 \mathrm{~K}$ & CX Completed \\
\hline CPP-603 Corrosion Control Power Upgrade (design) & GE-GPP & $300 \mathrm{~K}$ & CX Completed \\
\hline ICPP Protective Force Support Facility & GE-GPP & $950 \mathrm{~K}$ & CX Completed \\
\hline Plant Street Lighting Replacement and Upgrade & GE-GPP & $807 \mathrm{~K}$ & CX Completed \\
\hline Security Lighting Upgrade & GE-GPP & $90 \mathrm{~K}$ & CX Completed \\
\hline Upgrade DVB-C-37, C-12, C-32 (construction) & EW-GPP & $500 \mathrm{~K}$ & CX Completed \\
\hline Cathodic Protection System Upgrade & EW-GPP & $1,000 \mathrm{~K}$ & CX Completed \\
\hline Install Leak Detection FT-534/548/549 (Basin Sumps) & EW-GPP & $249 \mathrm{~K}$ & CX Completed \\
\hline
\end{tabular}

CX - Categorical Exclusion

EA - Environmental Assessment

EIS - Environmental Impact Statement

K - Thousands

M - Millions 
Table 1. ICPP FIVE-YEAR PROJECT SUMMARY (continued)

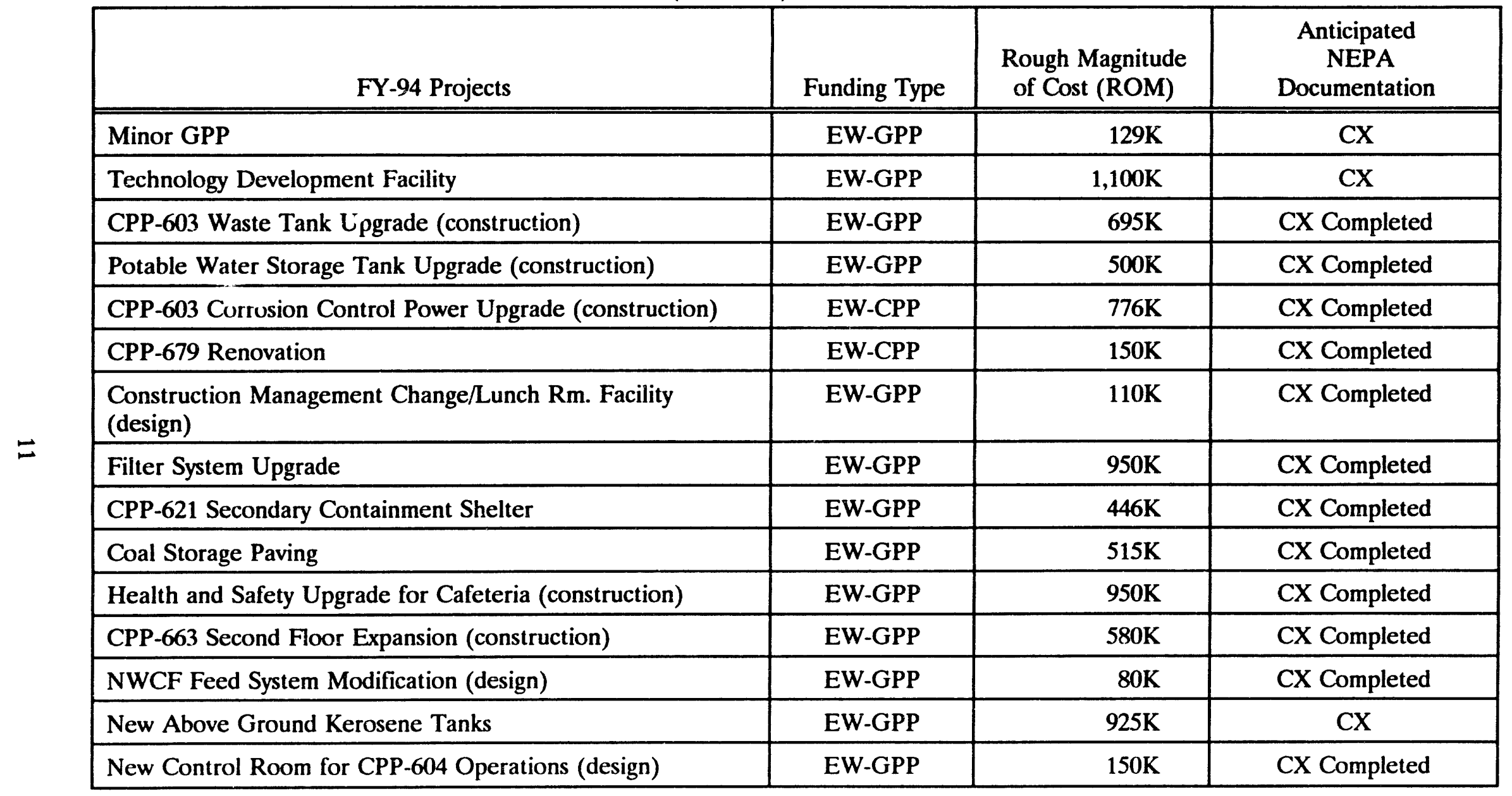


Table 1. ICPP FIVE-YEAR PROJECT SUMMARY (continued)

\begin{tabular}{|l|c|c|c|}
\hline \multicolumn{1}{|c|}{ FY-95 Projects } & Funding Type & $\begin{array}{c}\text { Anticipated } \\
\text { RePA } \\
\text { of Cost (ROM) }\end{array}$ & $\begin{array}{c}\text { Magnitude } \\
\text { Documentation }\end{array}$ \\
\hline \hline Minor GPP & EW-GPP & $20 \mathrm{~K}$ & CX \\
\hline ECF Dry Cell Cast Support Equipment & EW-GPP & $1,100 \mathrm{~K}$ & CX \\
\hline Construction Mgmt Change/Lunch Room Facility (construction) & EW-GPP & $950 \mathrm{~K}$ & CX Completed \\
\hline ICPP Retrievable Records Storage Area & EW-GPP & $1,400 \mathrm{~K}$ & CX \\
\hline NWCF Feed System Modification (construction) & EW-GPP & $575 \mathrm{~K}$ & CX \\
\hline Environmental Compliance Analytical Upgrade & EW-GPP & $1,100 \mathrm{~K}$ & CX \\
\hline New Control Room for CPP-604 Operations (construction) & EW-GPP & $950 \mathrm{~K}$ & CX Completed \\
\hline South CPP-621 Pipe Trench & EW-GPP & $485 \mathrm{~K}$ & CX \\
\hline New Tool Crib & EW-GPP & $500 \mathrm{~K}$ & CX \\
\hline Peach Bottom \& FERMI Dry Vaults Renovate & EW-GPP & $1,100 \mathrm{~K}$ & CX \\
\hline FH\&D Paved Storage Area & EW-GPP & $505 \mathrm{~K}$ & CX \\
\hline Security Facilities Upgrade & EM-LI & $18.5 \mathrm{M}$ & CX \\
\hline
\end{tabular}

\begin{tabular}{|l|c|c|c|}
\hline \multicolumn{1}{|c|}{ FY-96 Projects } & Funding Type & $\begin{array}{c}\text { Rough Magnitude } \\
\text { of Cost (ROM) }\end{array}$ & $\begin{array}{c}\text { Anticipated } \\
\text { NEPA } \\
\text { Documentation }\end{array}$ \\
\hline \hline Replace CPP-621 Transfer Lines & EW-GPP & $1,100 \mathrm{~K}$ & CX \\
\hline Renovation CPP-627 Analytical Laboratory & EW-GPP & $1,100 \mathrm{~K}$ & CX \\
\hline Contaminated Fuel Handling Equipment Storage Bldg. & EW-GPP & $1,100 \mathrm{~K}$ & CX \\
\hline FAST Facility Office at Maintenance Facility & EW-GPP & $1,100 \mathrm{~K}$ & CX \\
\hline Electrical \& Utilities Systems Upgrade & EM-LI & $75 M$ & CX or sitewide EIS \\
\hline \hline
\end{tabular}

Table 1. ICPP FIVE-YEAR PROJECT SUMMARY (continued) 


\begin{tabular}{|l|c|c|c|}
\hline \multicolumn{1}{|c|}{ FY-97 Projects } & Funding Type & $\begin{array}{c}\text { Rough Magnitude } \\
\text { of Cost (ROM) }\end{array}$ & $\begin{array}{c}\text { Anticipated } \\
\text { NEPA } \\
\text { Documentation }\end{array}$ \\
\hline \hline Calcine Recovery System for Bin Set \#1 & EM-LI & $50 \mathrm{M}$ & EIS \\
\hline Fuel Canning \& Dry Modular Storage & EM-LI & $60 \mathrm{M}$ & EIS \\
\hline Tank Farm Heel Removal & EM-LI & $34 \mathrm{M}$ & EA \\
\hline Laboratory Expansion \& Upgrade Project & EM-LI & $20 \mathrm{M}$ & CX \\
\hline
\end{tabular}

\begin{tabular}{|l|c|c|c|}
\hline \multicolumn{1}{|c|}{ FY-98 Projects } & Funding Type & $\begin{array}{c}\text { Rough Magnitude } \\
\text { of Cost (ROM) }\end{array}$ & $\begin{array}{c}\text { Anticipated } \\
\text { NEPA } \\
\text { Documentation }\end{array}$ \\
\hline \hline Waste Immobilization Facility & EM-LI & $1250 \mathrm{M}$ & Sitewide EIS \\
\hline
\end{tabular}




\begin{tabular}{|c|c|c|c|}
\hline ISSUE & SOLUTION & $\begin{array}{l}\text { REQUIRED } \\
\text { RESOURCES }\end{array}$ & $\begin{array}{l}\text { IMPACT IF NOT } \\
\text { PROVIDED }\end{array}$ \\
\hline $\begin{array}{l}\text { 1. ICPP tank farm } \\
\text { does not meet } \\
\text { RCRA secondary } \\
\text { containment } \\
\text { compatibility and } \\
\text { some tanks do } \\
\text { not meet DOE } \\
\text { seismic resistancy. }\end{array}$ & $\begin{array}{l}\text { Minimize waste } \\
\text { generation and } \\
\text { maximize NWCF } \\
\text { operation in the } \\
\text { short term, and } \\
\text { design, construct and } \\
\text { operate the Waste } \\
\text { Immobilization } \\
\text { Facility (WIF) in the } \\
\text { long term. }\end{array}$ & $\begin{array}{l}\text { Major system } \\
\text { acquisition of WIF }\end{array}$ & $\begin{array}{l}\text { Inability to meet the } \\
\text { consent order with } \\
\text { the State of Idaho. } \\
\text { Potential fines for } \\
\text { improper waste } \\
\text { storage and } \\
\text { prohibitions on } \\
\text { waste generation. }\end{array}$ \\
\hline $\begin{array}{l}\text { 2. Wastes processed } \\
\text { at the New Waste } \\
\text { Calcining Facility } \\
\text { (NWCF) contain } \\
\text { nitrate } \\
\text { compounds which } \\
\text { decompose to } \\
\mathrm{NO}_{\mathrm{x}} \mathrm{NO}_{\mathrm{x}} \\
\text { abatement is } \\
\text { required by State } \\
\text { permits. }\end{array}$ & $\begin{array}{l}\text { Pilot plant testing has } \\
\text { confirmed that } \mathrm{NO}_{\mathrm{x}} \\
\text { emissions can be } \\
\text { effectively reduced. } \\
\text { A full-scale facility } \\
\text { should be constructed } \\
\text { using this technology. }\end{array}$ & $\begin{array}{l}\text { Construct a facility to } \\
\text { reduce the release of } \\
\mathrm{NO}_{x} \text { gases to the } \\
\text { atmosphere. } \\
\mathrm{LI}-\mathrm{NO}_{x} \text { Abatement } \\
\underline{\text { Facility }}\end{array}$ & $\begin{array}{l}\text { HLW processing } \\
\text { rates at the NWCF } \\
\text { may be restricted to } \\
\text { mect State permit } \\
\text { requirements. Waste } \\
\text { inventories would } \\
\text { continue to increase. }\end{array}$ \\
\hline $\begin{array}{l}\text { 3. Several utilities } \\
\text { are rapidly } \\
\text { becoming } \\
\text { inadequate; utility } \\
\text { systems are } \\
\text { inefficient, out of } \\
\text { compliance, and } \\
\text { will not support } \\
\text { projected growth. }\end{array}$ & $\begin{array}{l}\text { Upgrade electrical } \\
\text { and utility systems to } \\
\text { enhance reliability } \\
\text { and availability, } \\
\text { correct deficiencies, } \\
\text { and provide adequate } \\
\text { sizing for existing and } \\
\text { planned facilities. }\end{array}$ & $\begin{array}{l}\text { Upgrade or extend } \\
\text { utilities to } \\
\text { accommodate existing } \\
\text { and planned plant } \\
\text { growth. } \\
\text { LI - Electrical and } \\
\text { Utilities Systems } \\
\text { Upgrade }\end{array}$ & $\begin{array}{l}\text { Failure to implement } \\
\text { these utility upgrades } \\
\text { would significantly } \\
\text { impact economical } \\
\text { development at } \\
\text { ICPP and perpetuate } \\
\text { noncompliant } \\
\text { electrical and utility } \\
\text { systems. }\end{array}$ \\
\hline
\end{tabular}




\begin{tabular}{|c|c|c|c|}
\hline ISSUE & SOLUTION & $\begin{array}{l}\text { REQUIRED } \\
\text { RESOURCES }\end{array}$ & $\begin{array}{l}\text { IMPACT IF NOT } \\
\text { PROVIDED }\end{array}$ \\
\hline $\begin{array}{l}\text { 4. Spent fuel } \\
\text { management } \\
\text { process } \\
\text { development and } \\
\text { fuel } \\
\text { characterization is } \\
\text { not complete and } \\
\text { in some cases, has } \\
\text { not been } \\
\text { initiated. }\end{array}$ & $\begin{array}{l}\text { Aggressively develop } \\
\text { and implement spent } \\
\text { fuel characterization } \\
\text { to support dry fuel } \\
\text { storage initiatives, } \\
\text { and long term } \\
\text { conditioning } \\
\text { processes. }\end{array}$ & $\begin{array}{l}\text { Expand pilot plant } \\
\text { facilities to } \\
\text { accommodate } \\
\text { increased research } \\
\text { and development } \\
\text { activities. } \\
\text { Fuel Canning and } \\
\text { Characterization } \\
\text { Facility } \\
\text { Construct spent fuel } \\
\text { dry storage } \\
\text { demonstration unit. } \\
\text { Modify current } \\
\text { facilit: for } \\
\text { characterization } \\
\text { requirements. }\end{array}$ & $\begin{array}{l}\text { Slow progress will } \\
\text { jeopardize the } \\
\text { State's confidence } \\
\text { with DOE in } \\
\text { addressing HLW and } \\
\text { spent fuel issues, and } \\
\text { delay progress on } \\
\text { dry/fuel storage } \\
\text { projects. }\end{array}$ \\
\hline $\begin{array}{l}\text { 5. HLW storage is } \\
\text { inadequate for } \\
\text { spent fuel and } \\
\text { immobilized } \\
\text { waste. }\end{array}$ & $\begin{array}{l}\text { Develop capabilities } \\
\text { to repackage spent } \\
\text { fuel for storage and } \\
\text { disposal. } \\
\text { Include interim } \\
\text { storage in design of } \\
\text { the Waste } \\
\text { Immobilization } \\
\text { Facility. }\end{array}$ & $\begin{array}{l}\text { Construct a facility to } \\
\text { repackage spent fuel. } \\
\text { LI - Fuel Canning } \\
\text { and Dry Modular } \\
\text { Storage Facility. } \\
\text { Provide interim } \\
\text { storage in the Waste } \\
\text { Immobilization } \\
\text { Facility for the glass- } \\
\text { ceramic product. }\end{array}$ & $\begin{array}{l}\text { Failure to implement } \\
\text { acceptable treatment } \\
\text { and storage will } \\
\text { likely lead to } \\
\text { improper storage } \\
\text { and RCRA } \\
\text { violations. }\end{array}$ \\
\hline $\begin{array}{l}\text { 6. Inadequate } \\
\text { capability exists } \\
\text { to characterize } \\
\text { waste and } \\
\text { environmental } \\
\text { samples according } \\
\text { to regulatory } \\
\text { requirements. }\end{array}$ & $\begin{array}{l}\text { Expand the existing } \\
\text { ICPP Remote } \\
\text { Analytical Laboratory } \\
\text { (RAL). Upgrade } \\
\text { CPP-602 Lab's and } \\
\text { build two new } \\
\text { Radiochemistry } \\
\text { Counting Facilities. }\end{array}$ & $\begin{array}{l}\text { Expand and construct } \\
\text { suitable facilities for } \\
\text { characterization and } \\
\text { lab work. } \\
\text { LI - Laboratory } \\
\text { expansion and } \\
\text { upgrade project. }\end{array}$ & $\begin{array}{l}\text { Could be out of } \\
\text { compliance with } \\
\text { RCRA waste } \\
\text { characterization } \\
\text { requirements for } \\
\text { treatment, storage, } \\
\text { and disposal (TSD) } \\
\text { facilities. May not } \\
\text { receive permits for } \\
\text { units if waste } \\
\text { characterization } \\
\text { methodologies are } \\
\text { inadequate. }\end{array}$ \\
\hline
\end{tabular}




\begin{tabular}{|c|c|c|c|}
\hline ISSUE & SOLUTION & $\begin{array}{l}\text { REQUIRED } \\
\text { RESOURCES }\end{array}$ & $\begin{array}{l}\text { IMPACT IF NOT } \\
\text { PROVIDED }\end{array}$ \\
\hline $\begin{array}{l}\text { 7. CSSE \#1 may not } \\
\text { meet DOE } \\
\text { seismic resistancy. } \\
\\
\\
\text { A calcine } \\
\text { retrieval concept } \\
\text { is developed, but } \\
\text { no operational } \\
\text { system exists. }\end{array}$ & $\begin{array}{l}\text { Construct a new } \\
\text { CSSF. } \\
\text { Develop, } \\
\text { demonstrate, and } \\
\text { construct an } \\
\text { operational system } \\
\text { for calcine retrieval. }\end{array}$ & $\begin{array}{l}\text { Build another CSSF. } \\
\text { LI - Calcine Bin Set } \\
\# 8 \\
\text { Construct a calcine } \\
\text { recovery system. } \\
\text { LI - Calcine } \\
\text { Recovery for Bin Set } \\
\# 1\end{array}$ & $\begin{array}{l}\text { Corrective measures } \\
\text { will not be available } \\
\text { if another CSSF is } \\
\text { not constructed and } \\
\text { a retrieval system is } \\
\text { not developed. This } \\
\text { technology is also } \\
\text { needed to transport } \\
\text { calcine from all } \\
\text { CSSFs to the Waste } \\
\text { Immobilization } \\
\text { Facility. }\end{array}$ \\
\hline $\begin{array}{l}\text { 8. Recovery of } \\
\text { isotope by- } \\
\text { products from } \\
\text { spent fuel has not } \\
\text { been addressed. }\end{array}$ & $\begin{array}{l}\text { Identify available uses } \\
\text { and markets for } \\
\text { isotope by-products. } \\
\text { Determine the } \\
\text { economic and safety } \\
\text { implications of } \\
\text { isotope usage. }\end{array}$ & $\begin{array}{l}\text { Fund studies related } \\
\text { to isotope recovery } \\
\text { and use. }\end{array}$ & $\begin{array}{l}\text { The loss of valuable } \\
\text { isotope resources } \\
\text { might be caused by } \\
\text { inadequate } \\
\text { evaluation of future } \\
\text { applications. }\end{array}$ \\
\hline $\begin{array}{l}\text { 9. Waste volumes } \\
\text { for D\&D and } \\
\text { environmental } \\
\text { restoration } \\
\text { projects are not } \\
\text { projected. } \\
\end{array}$ & $\begin{array}{l}\text { Develop plans for } \\
\text { characterizing and } \\
\text { projecting D\&D } \\
\text { waste volumes. }\end{array}$ & $\begin{array}{l}\text { Define closure } \\
\text { requirements. }\end{array}$ & $\begin{array}{l}\text { Future TSD facilities } \\
\text { may not have } \\
\text { adequate capability } \\
\text { to accommodate } \\
\text { forecasted D\&D } \\
\text { projects. }\end{array}$ \\
\hline $\begin{array}{l}\text { Proposed } \\
\text { DOE } \\
\text { standards } \\
\text { would } \\
\text { eliminate the } \\
\text { use of soil } \\
\text { columns } \\
\text { (percolation } \\
\text { ponds) for } \\
\text { disposal of } \\
\text { waste water. }\end{array}$ & $\begin{array}{l}\text { Develop an alternate } \\
\text { disposal method for } \\
\text { waste water. }\end{array}$ & $\begin{array}{l}\text { Construct a system to } \\
\text { provide cooling water } \\
\text { to each major process } \\
\text { facility along with } \\
\text { disposal for existing } \\
\text { chemical waste } \\
\text { streams. } \\
\text { LI - Service Waste } \\
\text { Cooling Water } \\
\text { Closed Loop System }\end{array}$ & $\begin{array}{l}\text { If regulations are } \\
\text { enacted that require } \\
\text { the elimination of } \\
\text { soil columns, ICPP } \\
\text { could be at risk of } \\
\text { having no place to } \\
\text { dispose of waste } \\
\text { water. }\end{array}$ \\
\hline $\begin{array}{l}\text { Treatment } \\
\text { options are } \\
\text { not } \\
\text { developed for } \\
\text { HLW subject } \\
\text { to RCRA } \\
\text { land disposal } \\
\text { restrictions. }\end{array}$ & $\begin{array}{l}\text { Develop and } \\
\text { implement processes } \\
\text { to treat HLW to } \\
\text { meet RCRA } \\
\text { requirements. }\end{array}$ & $\begin{array}{l}\text { Design and construct } \\
\text { a facility suitable for } \\
\text { immobilizing and } \\
\text { storing HLW in a } \\
\text { repository. } \\
\text { LI - HLW Waste } \\
\text { Immobilization } \\
\text { Facility }\end{array}$ & $\begin{array}{l}\text { Failure to implement } \\
\text { an acceptable HLW } \\
\text { treatment process } \\
\text { will likely lead to } \\
\text { RCRA violations/ } \\
\text { fines. }\end{array}$ \\
\hline
\end{tabular}




\begin{tabular}{|c|c|c|c|c|}
\hline & ISSUE & SOLUTION & $\begin{array}{l}\text { REQUIRED } \\
\text { RESOURCES }\end{array}$ & $\begin{array}{l}\text { IMPACT IF NOT } \\
\text { PROVIDED }\end{array}$ \\
\hline 12. & $\begin{array}{l}\text { RCRA } \\
\text { Hazardous } \\
\text { waste must } \\
\text { be removed } \\
\text { from the tank } \\
\text { farm tanks } \\
\text { after cease of } \\
\text { use. }\end{array}$ & $\begin{array}{l}\text { Develop and } \\
\text { implement } \\
\text { technology to clean } \\
\text { the tanks. }\end{array}$ & $\begin{array}{l}\text { LI - project for Tank } \\
\text { Farm Heel Removal }\end{array}$ & $\begin{array}{l}\text { State of Idaho fines } \\
\text { for failure to treat } \\
\text { and dispose of } \\
\text { RCRA waste. }\end{array}$ \\
\hline
\end{tabular}




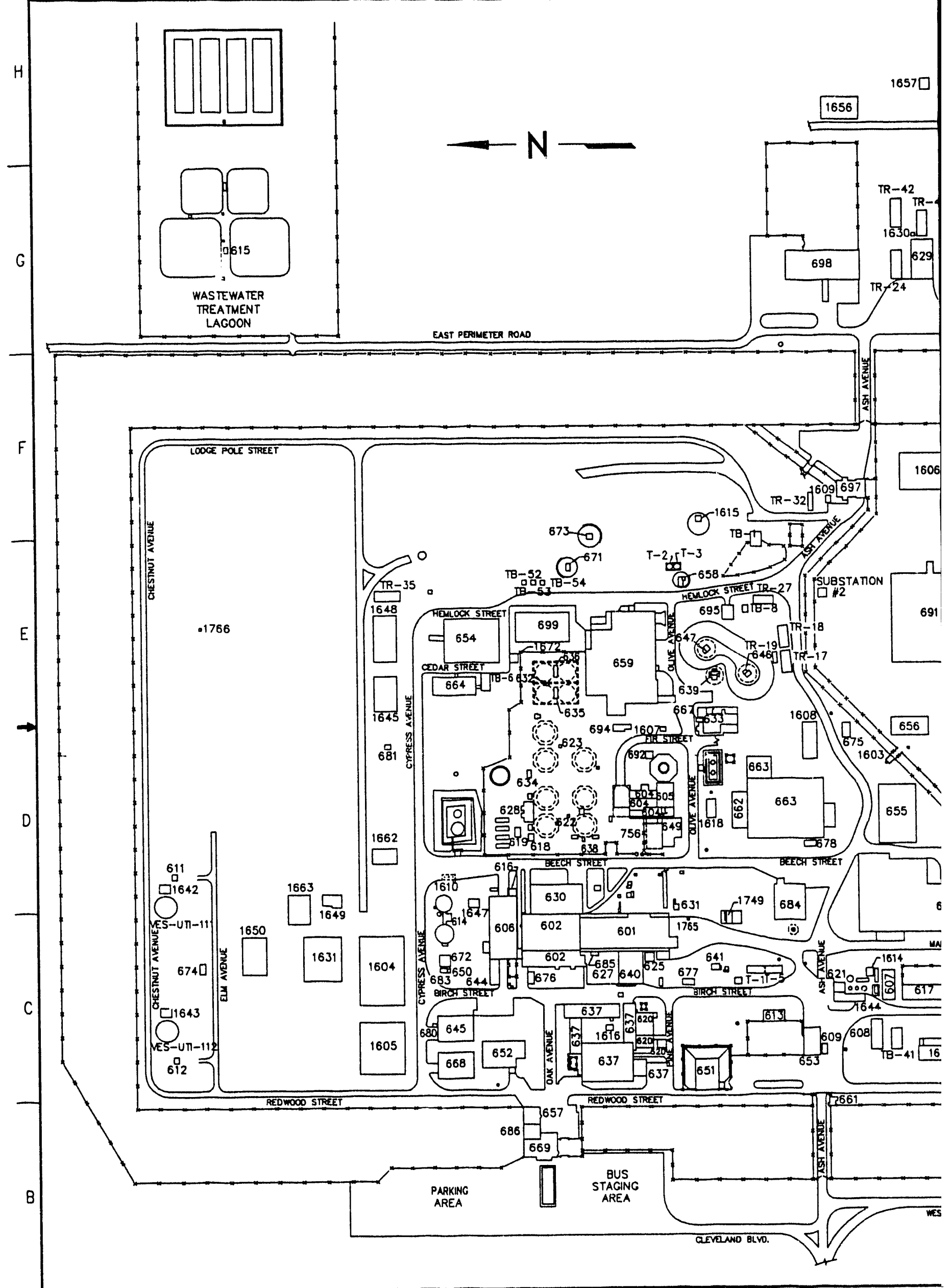




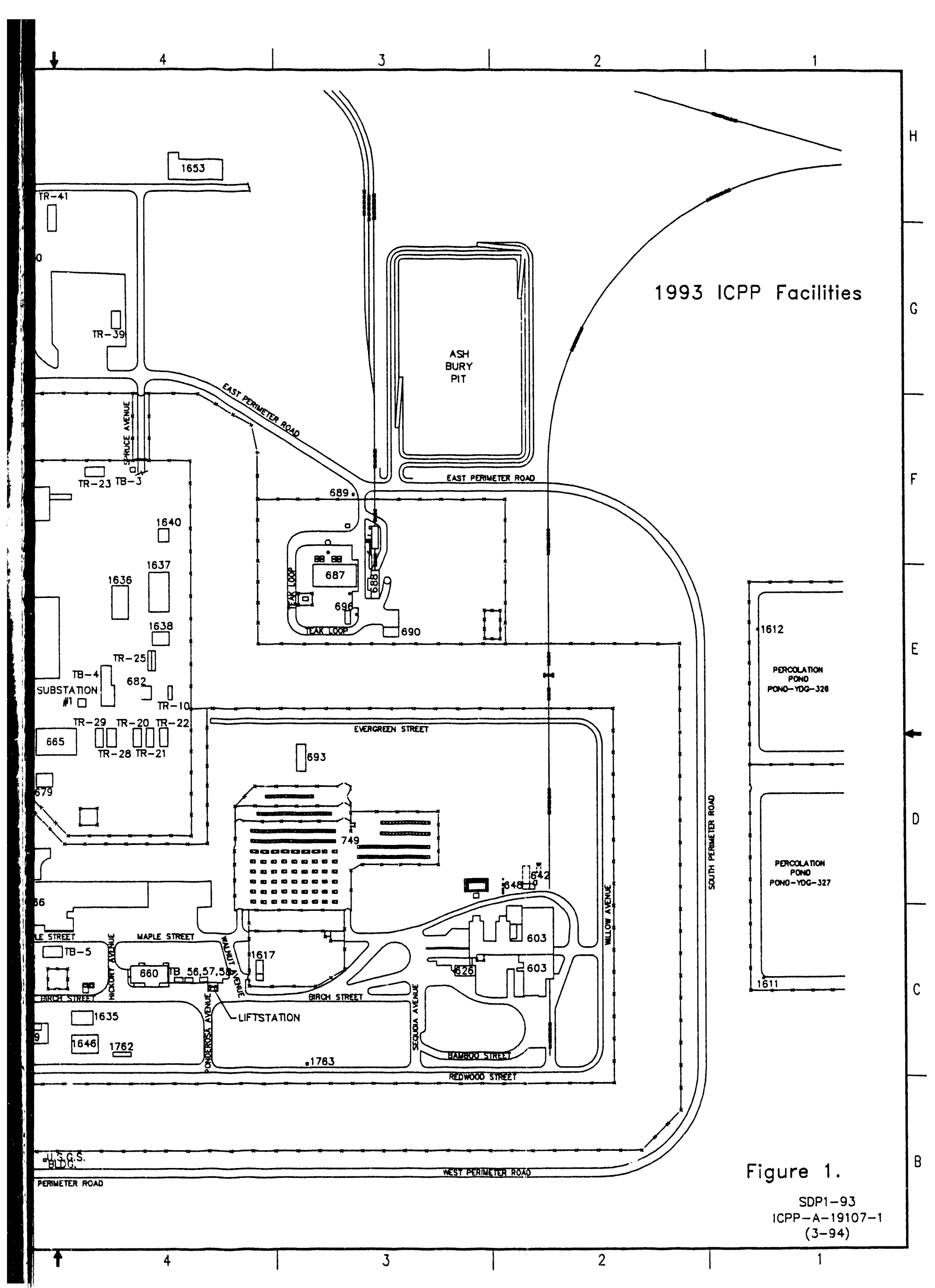




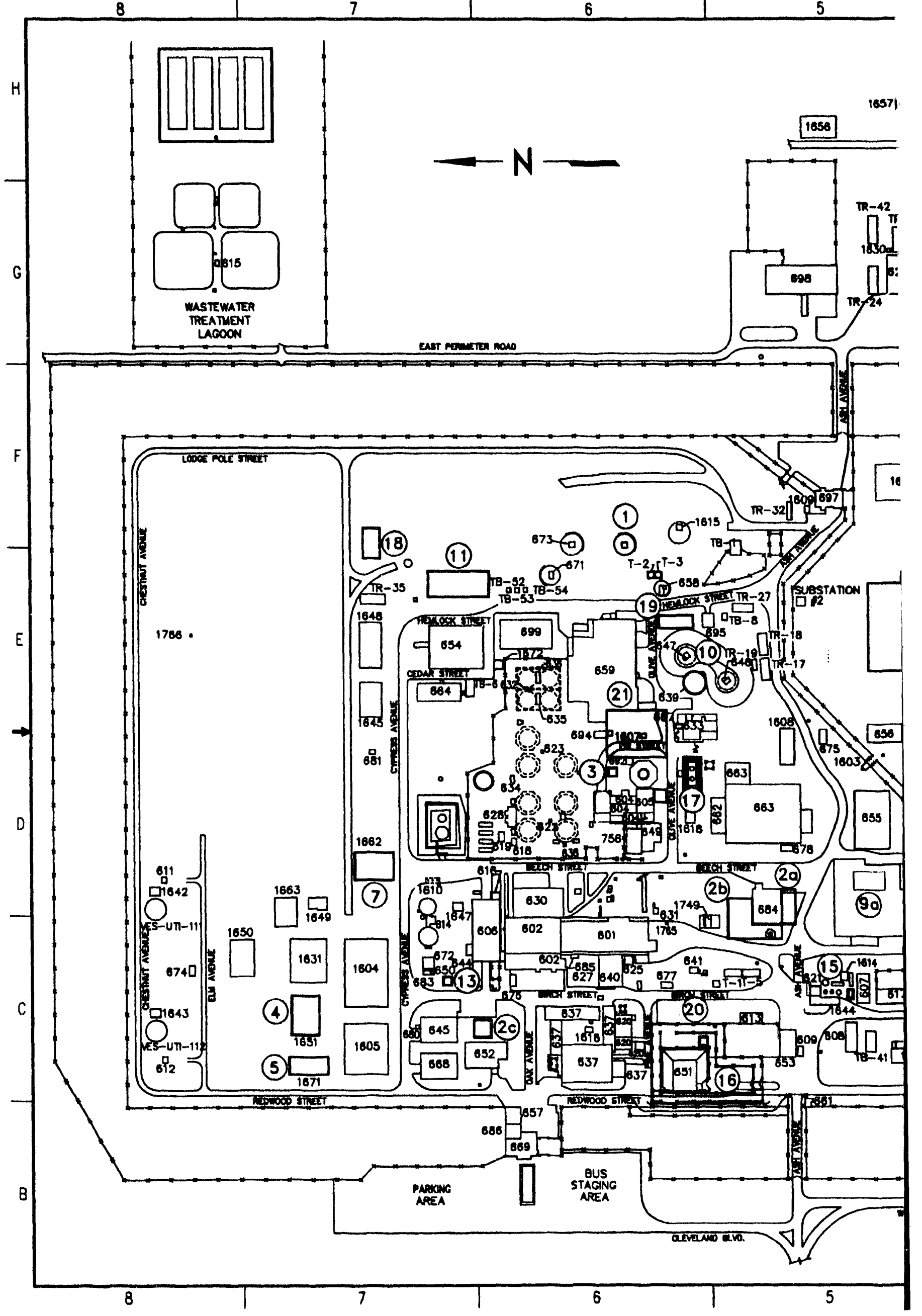


1
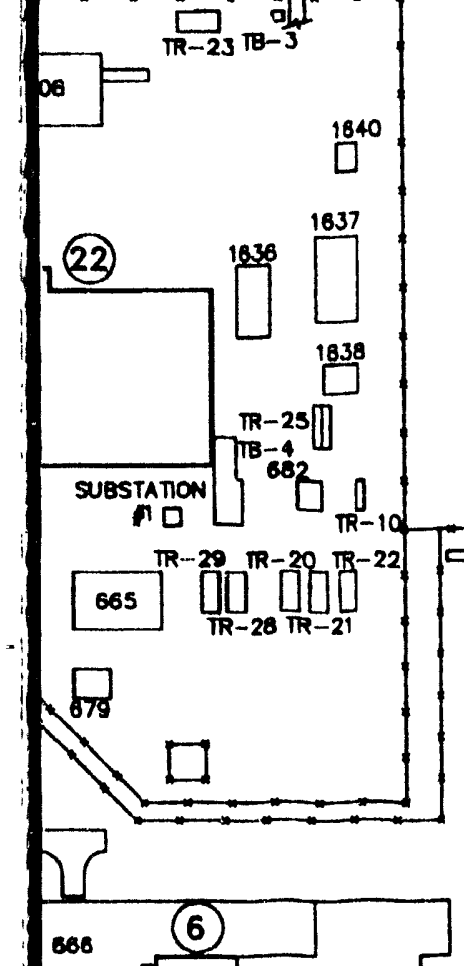

686
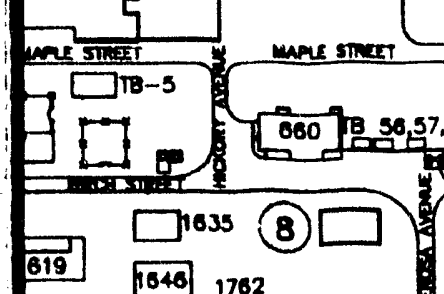

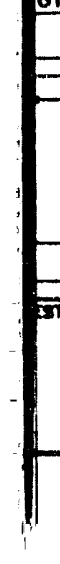



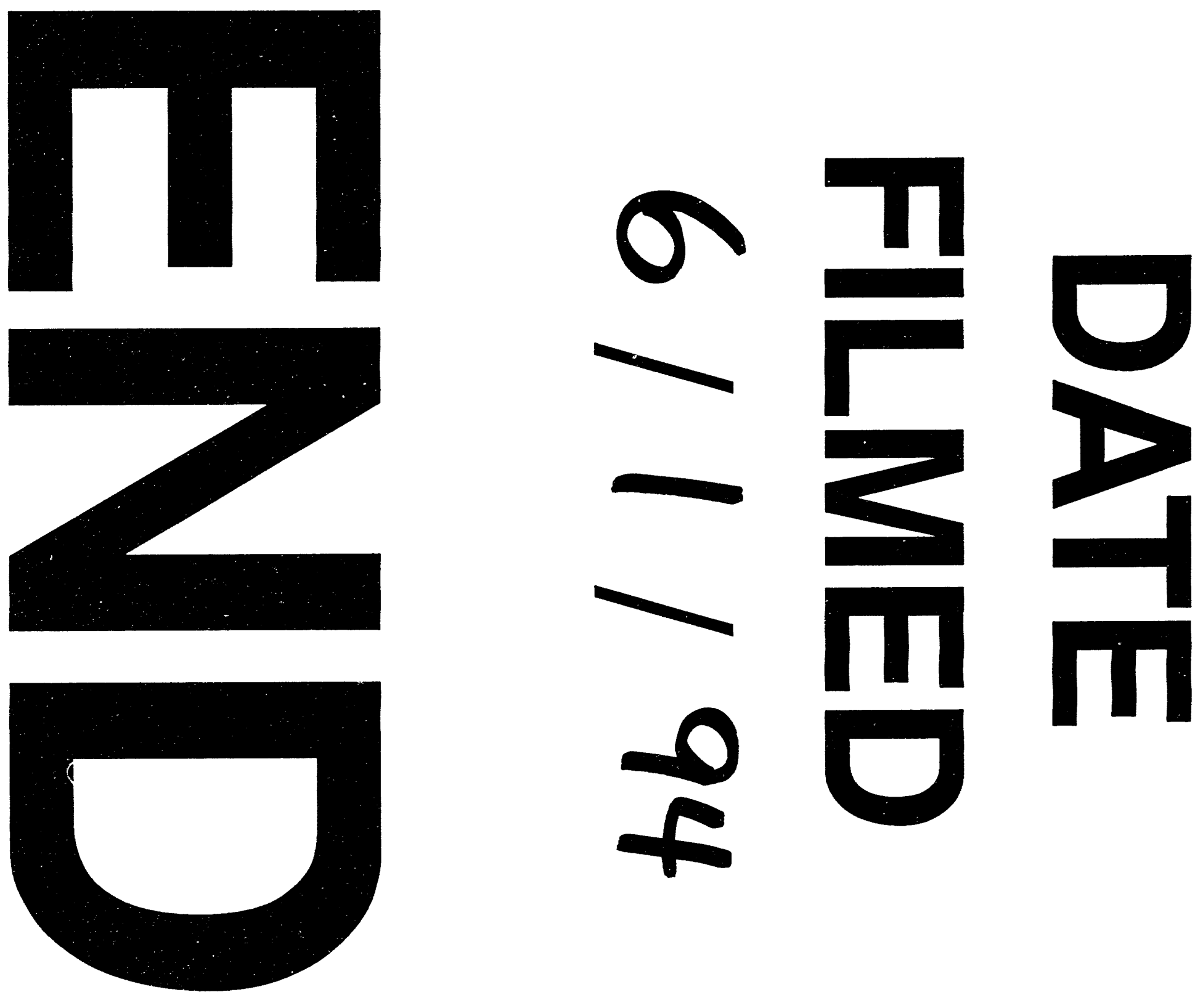

F 


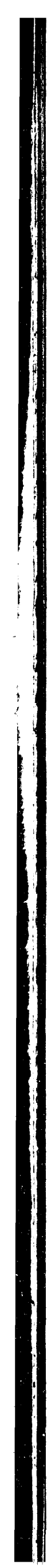

,

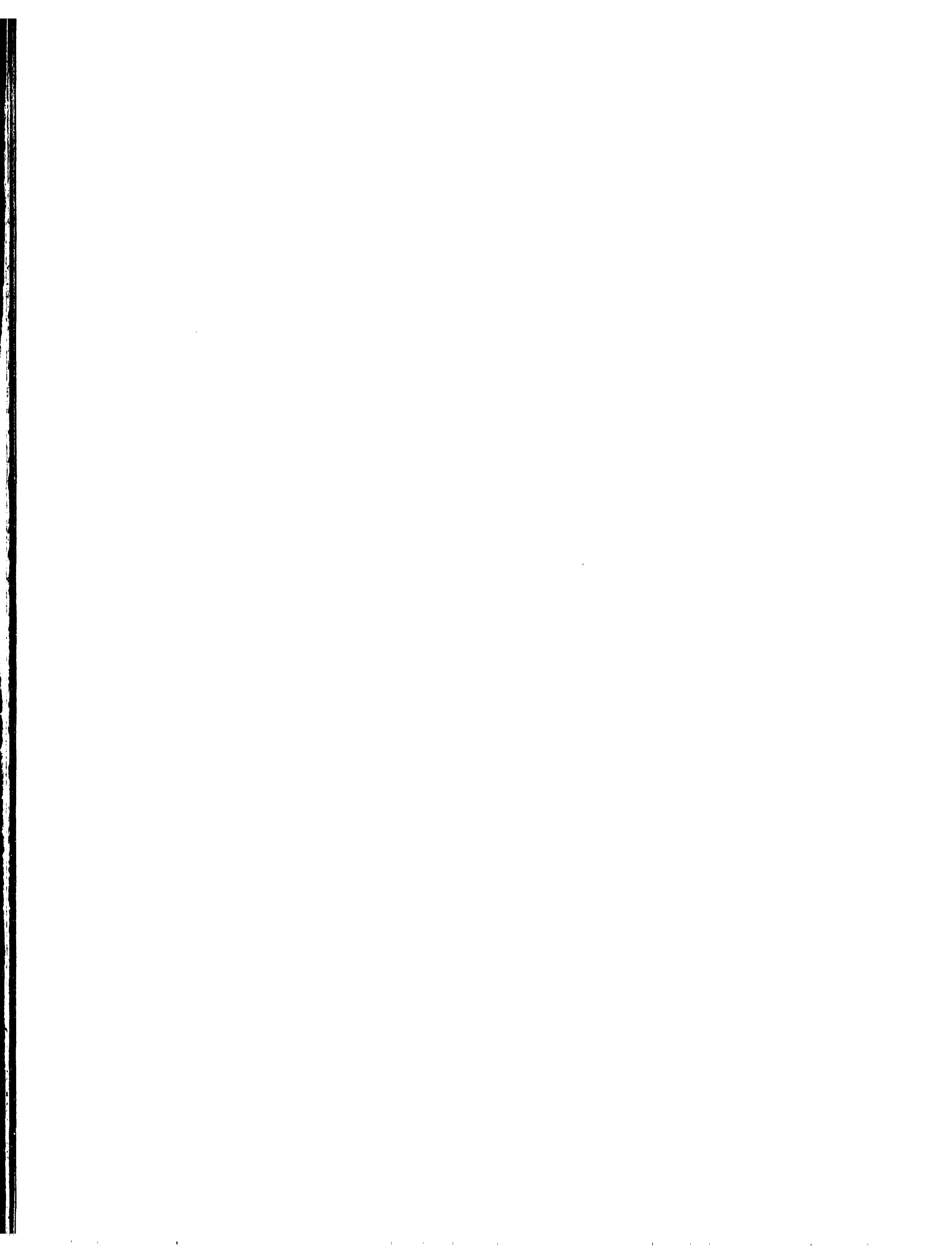

